\title{
Hemolysins of Staphylococcus aureus-An Update on Their Biology, Role in Pathogenesis and as Targets for Anti-Virulence Therapy
}

\author{
Sireesha Divyakolu1, Rosy Chikkala1, Kamaraju Suguna Ratnakar ${ }^{2}$, Venkataraman Sritharan ${ }^{3 *}$ \\ ${ }^{1}$ Department of Molecular Diagnostics \& Biomarkers, Global Medical Education \& Research Foundation (GMERF), \\ Hyderabad, India \\ ${ }^{2}$ Global Medical Education \& Research Foundation (GMERF), Hyderabad, India \\ ${ }^{3}$ Department of Molecular Diagnostics \& Biomarkers, Gleneagles Global Hospital, \& Secretary, Global Medical Education \& \\ Research Foundation (GMERF), Hyderabad, India \\ Email: dsiri.biotech@gmail.com, rosylikerose@gmail.com, kamaraju.ratnakar@gmail.com, \\ *venkataraman.sritharan@gmail.com
}

How to cite this paper: Divyakolu, S., Chikkala, R., Ratnakar, K.S. and Sritharan, V. (2019) Hemolysins of Staphylococcus aureus-An Update on Their Biology, Role in Pathogenesis and as Targets for Anti-Virulence Therapy. Advances in Infectious Diseases, 9, 80-104. https://doi.org/10.4236/aid.2019.92007

Received: March 12, 2019

Accepted: June 9, 2019

Published: June 12, 2019

Copyright $\odot 2019$ by author(s) and Scientific Research Publishing Inc. This work is licensed under the Creative Commons Attribution International License (CC BY 4.0).

http://creativecommons.org/licenses/by/4.0/ (c) (i) Open Access

\begin{abstract}
Staphylococcus aureus is a dangerous gram positive bacterial pathogen which, not only evades the host's immune system but also can destroy the leucocytes especially neutrophils. It has an embodiment of virulence factors most of which are secreted. Staphylococcus aureus secretes a number of toxins which cause tissue damage and facilitate spreading and nutrients uptake. Among the toxins, hemolysins $\alpha, \beta, \gamma, \delta$ and Panton Valentine Leukocidin $(\mathrm{PVL})$ are unique that they drill pores in the membrane, leading to the efflux of vital molecules and metabolites. Hemolysins also help in the scavenging of iron, although many of them also have leucolytic properties. $\alpha$-hemolysin, also known as $\alpha$-toxin, is the most prominent cytotoxin which damages a wide range of host cells including epithelial cells, endothelial cells, erythrocytes, monocytes, keratinocytes and it damages cell membrane and induces apoptosis. $\beta$-Hemolysin significantly affects human immune cell function. It has $\mathrm{Mg}^{2+}$ dependent sphingomyelinase activity and degrades sphingomyelin of plasma membrane into phosphorylcholine and ceramides. The bi-component leukocidins, which include $\gamma$-hemolysin and PVL, attack human phagocytic cells and greatly contribute to immune evasion. Delta toxin is a low molecular weight exotoxin with a broad cytolytic activity. Virulence determinants, quorum sensing and biofilm synthesis provide some attractive targets for design and development of a new group of antimicrobial compounds. This review provides an update on the structure, biological functions of hemolysins and their role in quorum sensing/biofilm synthesis (if any) and as effective therapeutic targets for anti-virulence drug development. We have tried to bring
\end{abstract}


together information available on various aspects of hemolysins and highlighted their distribution among all species of Staphylococcus and other bacteria. We have updated the status of development of candidate drugs targeting the hemolysins for anti-virulence therapy as it offers an additional strategy to reduce the severity of infection and which would, through quorum quenching, delay the development biofilms leading to drug resistance.

\section{Keywords}

Staphylococcus aureus, Hemolysins, PVL, Quorum Sensing, Biofilm, Anti-Virulence Therapy

\section{Introduction}

S. aureus, which was first discovered by Sir Alexander Ogston in 1880 [1], has long been recognized as a serious threat to human health, capable of causing a multitude of infections. It is a commensal bacterium which doubles-up as one of the most common human pathogens causing both nosocomial and community-acquired infections. It produces a variety of virulence factors depending on the site of infection ranging from minor skin infections to life-threatening diseases such as osteomyelitis, endocarditis, skin and soft tissue infection, brain abscesses, meningitis, bacteremia and pneumonia [1].

A major pathogenic attribute of $S$. aureus is to escape both innate and adaptive immune responses wherein a number of virulence factors including surface components such as the capsule, coagulase, protein A, teichoic acid, polysaccharides and adhesins; enzymes such as esterases, lipases, fatty-acid modifying enzymes, various proteases, hydrolytic enzymes, catalase, $\beta$-lactamase and various toxins such as leukocidin, enterotoxins, TSST-1 and alpha, beta, gamma and delta hemolysins [2], play important roles. Interestingly, several of these secreted exotoxins are directed to damage the host cells plasma membrane. Of the wide variety of Staphylococcalcytolytic exotoxins produced, the most prominent and well-characterized ones are the hemolysins, which play an important role in the Staphylococcal disease pathogenesis and have the ability to kill a variety of host cell populations including immune cells and help the bacteria to spread within the host [3]. The first report of hemolytic activity of Staphylococci recovered from human lesions appeared in 1894 and subsequently in 1900 [4].

Virulence determinants, quorum sensing and biofilm synthesis provide some attractive targets for the design and development of a new group of antimicrobial compounds. This review provides an update on the structure, biological functions of hemolysins and their role in quorum sensing/biofilm synthesis (if any) and as effective therapeutic targets for anti-virulence drug development. We have tried to bring together information available on various aspects of hemolysins and highlighted their distribution among all species of Staphylococcus and other bacteria. We have updated the status of development of candidate drugs 
targeting the hemolysins for anti-virulence therapy as it offers an additional strategy to reduce the severity of infection and which would, through quorum quenching, delay the development biofilms leading to drug resistance.

Alpha toxins are especially hemolytic to rabbit erythrocytes though they act on a wide range of mammalian cells including human erythrocytes. This toxin is a heptamer, toxic to epithelial cells, dermonecrotic and neurotoxin in human host [5]. Currently, pore formation by $\alpha$-toxin at the molecular level is being investigated. $\boldsymbol{\beta}$-toxin is magnesium-dependent sphingomyelinase that is active on sheep erythrocytes [6]. $\boldsymbol{\gamma}$-toxin is a two-component exotoxin which comprises of six different combinations of proteins active against erythrocytes [5]. $\delta$-toxin is a low molecular weight toxin with the ability to lyse many cell types [7]. Generally, $S$. aureus infection is multifactorial due to the combined action of several virulence determinants. One exception is toxinoses, which are caused by toxic shock syndrome toxin, exfoliative toxins A\&B and different Staphylococcal enterotoxins [8].

\section{Virulence Factors}

Virulence factors play several roles in the host including invasion, mediating immune suppression, and degrading host cells or tissues to obtain space for spreading or to acquire nutrients for bacterial growth [5]. Several factors contribute to $S$. aureus pathogenicity, like the surface proteins which mediate bacterial adherence to host cells, secretion of series of extracellular toxins, and enzymes which destroy the host's cells and tissues, help the bacteria to escape from host immune defense, growth and spread of bacteria in the host [8]. Extracellular toxins are proteins secreted by $S$. aureus during the post exponential and early stationary phases. In vitro and in vivo studies in animals revealed that Pore Forming Toxins (PFT) are major virulence factors involved in the pathophysiology of Staphylococcal infections. These toxins are capable of targeting a wide variety of immune cells during infection, such as human polymorphonuclear leukocytes, monocytes and macrophages and help the bacteria to escape from both innate and adoptive immune responses [8]. Hemolysins are not only present in staphylococcal species (Table 1) but also in several other pathogenic bacteria (Table 2 and Figure 1).

Genome analyses revealed that there are different sets of genes encoding different virulence factors in $S$. aureus. This heterogeneity is due to the fact that many of these genes are located in pathogenicity islands wherein genes are translocated by Horizontal Genome Transfer (HGT) via phage transduction, conjugation or by direct uptake of naked DNA by genetic competence [27].

\subsection{Alpha Hemolysin (Alpha-Toxin, Hla)}

\subsubsection{Discovery}

Initial studies on investigation of the toxic activity of staphylococcal supernatants began in the late 1800s. These toxic substances secreted by $\mathcal{S}$. aureus were attributed lethality in guinea pigs and rabbits, dermonecrosis, inflammation of 
the conjunctival epithelium and hemolysis [28]. Investigation of $\alpha$-toxin arose by a tragedy in the Australian town of Bundaberg in 1928. Twenty one children who were vaccinated with a diphtheria toxoid became severely ill and 12 died. Investigating the cause of this disaster, Burnet reported that the toxic properties of crude exo-substance from $S$. aureus led to the identification of $\alpha$-toxin as a major cause of the observed toxicity [29].

Table 1. Hemolysins from Staphylococcal species.

\begin{tabular}{|c|c|c|c|c|}
\hline S. No & $\begin{array}{l}\text { Staphylococcal } \\
\text { species }\end{array}$ & $\begin{array}{c}\text { Type of } \\
\text { hemolysin }\end{array}$ & $\begin{array}{l}\text { Disease } \\
\text { pathology }\end{array}$ & Ref \\
\hline 1 & $\begin{array}{c}\text { Staphylococcus } \\
\text { aureus }\end{array}$ & $\alpha, \beta, \gamma, \delta$ & Sepsis & [9] \\
\hline 2 & $\begin{array}{l}\text { Staphylococcus } \\
\text { auricularis }\end{array}$ & $\alpha$ & $\begin{array}{c}\text { Weak or Moderate hemolysins } \\
\text { associated with sepsis }\end{array}$ & {$[10]$} \\
\hline 3 & $\begin{array}{l}\text { Staphylococcus } \\
\text { carnosus }\end{array}$ & Lack of hemolysins & - & {$[11]$} \\
\hline 4 & $\begin{array}{l}\text { Staphylococcus } \\
\text { epidermidis }\end{array}$ & $\alpha, \delta$ & $\begin{array}{l}\text { CoNS species, plays a role in } \\
\text { catheter-associated blood } \\
\text { stream infections }\end{array}$ & {$[12]$} \\
\hline 5 & $\begin{array}{l}\text { Staphylococcus } \\
\text { haemolyticus }\end{array}$ & $\alpha, \delta$ & $\begin{array}{l}\text { CoNS, associated with blood } \\
\text { stream infections in Neonates }\end{array}$ & {$[10]$} \\
\hline 6 & $\begin{array}{c}\text { Staphylococcus } \\
\text { hyicusintermedius }\end{array}$ & $\delta$ & $\begin{array}{l}\text { Associated with } \\
\text { bovine mastitis }\end{array}$ & {$[13]$} \\
\hline 7 & $\begin{array}{l}\text { Staphylococcus } \\
\text { lugdunensis }\end{array}$ & $\delta$ & $\begin{array}{l}\text { Common cause of Skin } \\
\text { and soft tissue infections }\end{array}$ & {$[14]$} \\
\hline 8 & $\begin{array}{l}\text { Staphylococcus } \\
\text { saprophyticus }\end{array}$ & $\alpha$ & $\begin{array}{l}\text { Associated with uncomplicated } \\
\text { urinary tract infections }\end{array}$ & {$[15][16]$} \\
\hline 9 & $\begin{array}{l}\text { Staphylococcus } \\
\text { sciuri }\end{array}$ & $\beta, \delta$ & $\begin{array}{l}\text { Associated with mastitis in } \\
\text { animal infections. In humans, it } \\
\text { causes wound and soft tissue } \\
\text { infections, abscess, boils, } \\
\text { peritonitis, and endocarditis }\end{array}$ & {$[17]$} \\
\hline 10 & $\begin{array}{l}\text { Staphylococcus } \\
\text { simulans }\end{array}$ & $\delta$ & Urinary tract \& wound infections & {$[18]$} \\
\hline 11 & $\begin{array}{c}\text { Staphylococcus } \\
\text { warneri }\end{array}$ & $\delta$ & Septic arthritis & {$[10]$} \\
\hline
\end{tabular}

Table 2. Hemolysins from different bacterial species.

\begin{tabular}{lcccc}
\hline S. No & Organism & Type of Hemolysins & Salient features & Ref \\
\hline Escherichia coli & hlyA $(\alpha$-hln) & $\begin{array}{c}\text { Forms pores on the host cell } \\
\text { membrane; potentially toxic to } \\
\text { monocytes, lymphocytes and } \\
\text { macrophages }\end{array}$ & {$[19]$} \\
& & \multicolumn{4}{c}{$\begin{array}{c}\text { Cytotoxin, acts on epithelial cells } \\
\text { (pore formation) causes ATP }\end{array}$} & {$[20]$} \\
& Serratia marcescens & shlA & depletion and potassium efflux & \\
\hline
\end{tabular}




\section{Continued}

\begin{tabular}{|c|c|c|c|c|}
\hline 3 & Aeromonas hydrophila & $\beta$-hln & Epithelial barrier impairment & [21] \\
\hline 4 & $\begin{array}{l}\text { Listeria } \\
\text { monocytogenes }\end{array}$ & Listeriolysin-O (LLO) & $\begin{array}{c}\text { Pore forming cholesterol } \\
\text { dependent cytolysin, lysis of the } \\
\text { phagosome }\end{array}$ & [22] \\
\hline 5 & $\begin{array}{l}\text { Streptococcus } \\
\text { pneumoniae }\end{array}$ & $A$-hln/pneumolysin & $\begin{array}{c}\text { Membrane pore forming } \\
\text { toxin-causes inflammation in } \\
\text { meningeal membrane leads to } \\
\text { meningitis }\end{array}$ & [23] \\
\hline 6 & Plasmodium & $\begin{array}{c}\text { Plasmodium hemolysin } \\
\text { III (PfhlyIII) }\end{array}$ & $\begin{array}{c}\text { Lysis of erythrocytes leading to } \\
\text { hemolytic anemia }\end{array}$ & [24] \\
\hline 7 & Leptospirasps & $\begin{array}{c}\beta \text {-hln } \\
\text { sphingomyelinase }\end{array}$ & $\begin{array}{l}\text { Phospholipases act on erythrocytes } \\
\text { and other cell membranes } \\
\text { containing phospholipid as a } \\
\text { substrate-causes hemolysis and } \\
\text { hematuria }\end{array}$ & [25] \\
\hline 8 & Bacillus cereus & $\begin{array}{c}\text { Bacillus cereus } \\
\text { Sphingomyelinase } \\
\text { (Bc-SMase) }\end{array}$ & $\begin{array}{l}\text { Lysis of erythrocytes which } \\
\text { contains sphingomyelin }\end{array}$ & [26] \\
\hline
\end{tabular}

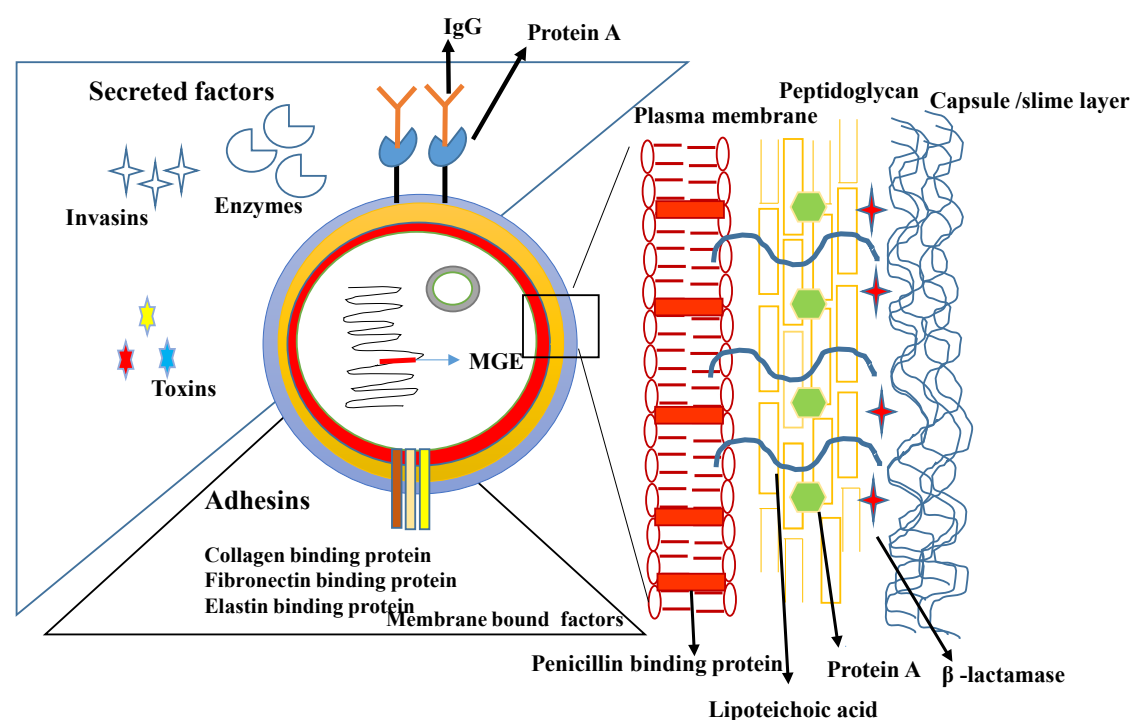

Figure 1. Virulence factors in S. aureus.

\subsubsection{Chemical Nature of Alpha-Toxin}

The alpha $(\alpha)$ gene/toxin is located on the bacterial chromosome [30] and is one of the best characterized pore forming toxin encoded by the hla. It plays an important role in $S$. aureus infections including pneumonia, skin and soft tissue infections [SSTI], sepsis, septic arthritis, brain abscess and corneal infections [31] [32] [33] [34] [35]. The exotoxin is a secreted protein of 293 amino acids (no cysteine) and has pI of about 8.5, endowed with hemolytic, cytotoxic, dermonecrotic and lethal properties. Circular Dichroism studies discovered that the mature toxin is composed almost entirely of $\beta$-strands [36]. This $33 \mathrm{kDa}$ pore forming toxin is expressed as a monomer by almost all the clinical isolates of $S$. 
aureus that assemble to form a membrane-bound heptameric $\beta$-barrel pore $(232.4 \mathrm{kD})$.

Though $\alpha$-toxin is active against a wide range of mammalian cells, it displays species and cell type specificity. It is predominantly active against rabbit erythrocytes when compared to human erythrocytes and other mammals and this toxin at, as low as $1 \mu \mathrm{g}$ is lethal when injected into rabbits intravenously. Human lymphocytes and monocytes are $\alpha$-hemolysin susceptible (maximum lysis at 100 $\mathrm{ng} \cdot \mathrm{ml}^{-1}$ ) whereas granulocytes are highly resistant to $\alpha$-hemolysin (no lysis even at $10 \mu \mathrm{g} \cdot \mathrm{ml}^{-1}$ ) [37]. Lysis of human lung epithelial cells (A549) is observed at high $\alpha$-hemolysin concentrations $\left(30 \mu \mathrm{g} \cdot \mathrm{ml}^{-1}\right)$ [38].

\subsubsection{Structure of $\alpha$-Hemolysin}

Structure of $\alpha$-hemolysin protein has been resolved by X-ray crystallography. It is expressed as a water-soluble monomer $(33.2 \mathrm{kDa})$ which assembles to form a membrane-bound heptameric pore on the susceptible cells. It is a mushroom-shaped protein and is divided into three sub-domains (Figure 2).

1) Cap domain: It is the external part and is largely hydrophobic in nature and is essential for the entry into the pore; each monomer contains two six stranded anti-parallel $\beta$-sheets which are exposed to the extra-cellular medium.

2) Rim domain: It is the base of the cap, in close proximity to membrane bilayer; charged amino acid residues at the lateral surfaces of the rim may provide contact sites with polar head groups of lipids in host cell membranes. Several aromatic amino acids (tryptophan, tyrosine) at the base of the rim may provide the contact sites for the interaction of pre-pore with the hydrophobic lipid environment of the plasma membrane

3) Stem/Trans membrane domain: This is largely hydrophilic in nature, forming the membrane-perforating $\beta$-barrel pore [31]. The residues 118-140 in the sequence of alpha-hemolysin or $\alpha$-toxin (Hla) monomer form the main portion of the pre-stem domain. Replacement of histidine residue at 35 positions by leucine completely gets the transition of alpha-hemolysin or $\alpha$-toxin (Hla) heptamer from the pre-pore to the pore formation stage [38].

\subsubsection{Mode of Action}

The lethal properties of $\alpha$-toxin are probably due to its effect on cells involved in the maintenance of homeostasis. Pore formation is a multi-step process; which includes secretion of $\alpha$-hemolysin monomers, which bind to target membranes, oligomerize to form a functional heptameric pore complex, the pre-pore. Susceptible cells have specific receptors which allow the alpha toxin to bind, causing small pores of $14 \AA$ resulting in the leakage of small cytoplasmic contents less than $2 \mathrm{kDa}$, like $\mathrm{Ca}^{2+}, \mathrm{K}^{+}$, altering the ion gradients and eventually causing death of the cell [28]. The pore concept has been widely accepted (Figure 3).

Interaction of alpha-hemolysin or Hla with host cells is concentration dependent. At higher concentration of $\alpha$-hemolysin, pore formation is recep- 
tor-independent and is likely mediated by the interaction between $\alpha$-hemolysin and phosphocholine head groups but at lower concentration pore formation is dependent on the interaction of receptor. Pore formation and subsequent cell lysis do not occur at concentrations below $33 \mathrm{ng} / \mu \mathrm{L}$ [39]. However, the recent findings suggest that $\alpha$-hemolysin associates with a receptor protein ADAM10 (A Disintegrin and Metalloprotease 10). ADAM10 is a zinc-dependent metalloprotease that is expressed on the surface of many distinct cell types as a type 1 trans-membrane protein. Upon binding of $\alpha$-hemolysin with ADAM10, the complex re-localizes to caveolin-1enriched lipid rafts that serve as a platform for the series of intracellular signal events and this interaction was diminished upon si-RNA mediated knockdown of ADAM10 [38]. $\alpha$-hemolysin binding to different cell types like RBC and human epithelial cells correlates with ADAM10 expression. Sequential binding to these different receptors (ADAM10 \& Caveolin) might trigger a conformational change allowing $\alpha$-hemolysin oligomerization to initiate cell specific lysis.

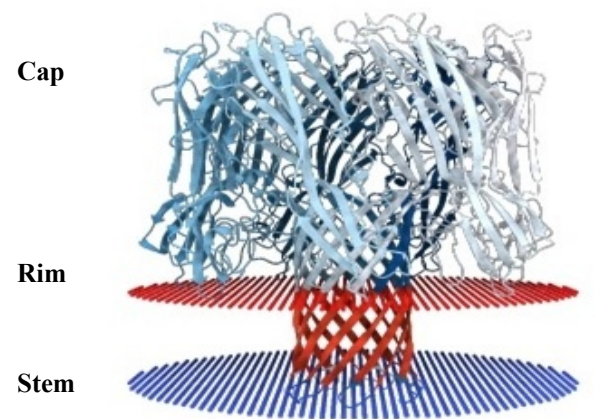

Figure 2. Structure of $\alpha$-hemolysin (PDB ID: 7 AHL).

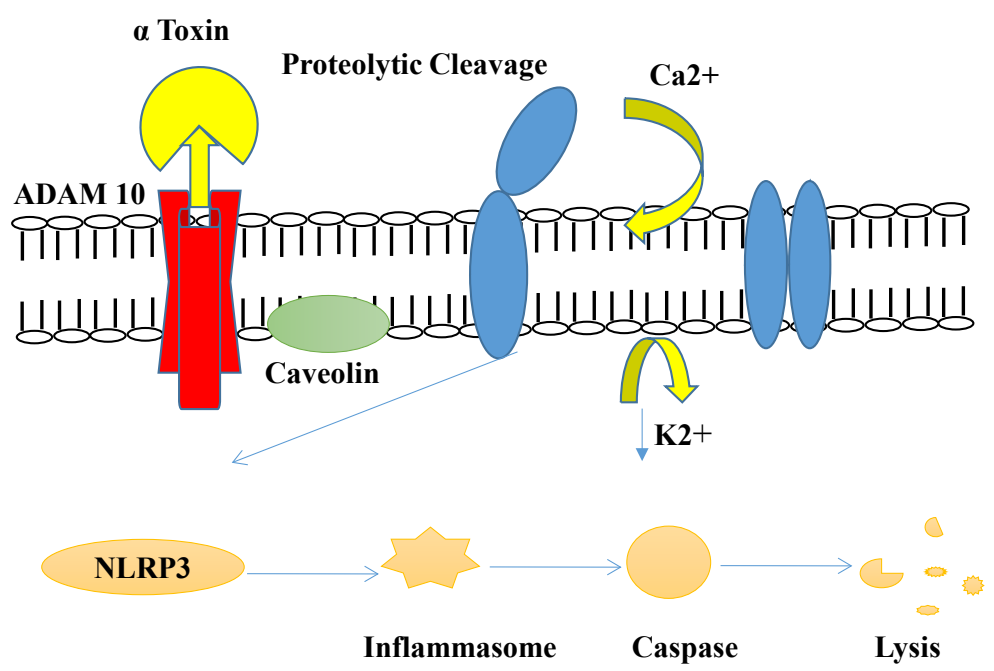

Figure 3. Mechanism of Action of alpha hemolysin: 1) $\alpha$-toxin binds to cell membrane receptor ADAM10. 2) Rise in $\mathrm{Ca}^{2+}$ and rapid fall in $\mathrm{K}^{+}$. 3) Activation of NLRP3 inflammasome. 4) Caspase-1 activation which leads to cell lysis [31]. 


\subsubsection{Pathophysiology}

The pore formation actually depends on the concentrations of alpha-hemolysin or $\alpha$-toxin (Hla) monomers in the medium and the presence of receptors in cell membrane. Experimental evidence indicates that only one or two potential receptors for Hla monomers exist in mammalian cells, i.e. ADAM10 and alpha-5-beta-1integrin [38] [40] and it is not known whether there are other receptors. Interaction of $\alpha$-hemolysin with ADAM10 ultimately leads to the disruption of focal adhesions by dephosphorylation of structural proteins like FAK (Focal Adhesion Kinase), paxillin, Src (Tyrosine protein kinase), and p130Cas (involved in cellular adhesion) which provide tensile strength to the barrier [38]. Alpha toxin induces the release of cytokines and chemokines. Excessive production of interleukin- $1 \beta$ and TNF- $\alpha$ results in tissue injury during inflammation. This toxin also induces apoptosis in human T-cell and monocytes. Neurotoxicity by $\alpha$-toxin was observed due to the destruction of myelin in rabbit nerves and in the murine cerebral cortex [28]. Low doses of the toxin enhance phagocytosis and the intracellular killing of neutrophils.

Production of pore forming toxins PVL and Hla facilitates the pathogenesis of pneumonia in $S$. aureus/MRSA infections and an increase in the incidence of severe pneumonia [41]. Immunization of mice with inactive $\alpha$-toxin protected mice against $S$. aureus pneumonia [32]. Hla mutants of $S$. aureus display reduced virulence in invasive disease models of pneumonia [32] [41] dermonecrotic skin infection, sepsis, peritonitis, and infection of the cornea [34], central nervous system [33], endocardium, and the mammary gland. However when the mutated $\alpha$-toxin gene in the knock out strain was complemented, the pathology was restored. S. aureus (USA300) displays increased hla expression and virulence in experimental models by accessory gene regulator (agr) and staphylococcal accessory element ( $s a e$ ) regulatory system which controls the toxin expression. In vivo studies revealed that alpha-hemolysin could be a useful target in the treatment of staphylococcal mastitis.

Moreover $\alpha$-toxin has the ability to alter the platelet morphology and hence may influence the thrombotic events associated with $S$. aureus sepsis [42].

Most of the staphylococcal exo-proteins are synthesized at post-logarithmic phase under the control of agr (accessory gene regulator). The actual effector of this global regulatory system is RNAIII which stimulates the transcription of genes coding for exo-proteins. Expression of $\alpha$-toxin is also controlled by a two-component system named as Agr system which was first identified by Recseietal [43], expression can also be modulated by other regulators, such as $S$. aureusexo-protein Response regulator (SaeR), Staphylococcal accessory regulator Z (SarZ), signal transduction histidine protein kinase (ArIS) (up-regulators) and Repressor protein gene (Rot), Staphylococcal accessory regulator (SarT) (down-regulators).

\subsubsection{As a Drug Target}

Alpha hemolysin, has received significant attention as a target for anti-toxin 
neutralizing antibodies. Anti- $\alpha$-hemolysin antibodies provide protection against lethal staphylococcal pneumonia caused by $S$. aureus in experimental studies [44] [45] and significantly reduced abscess formation in an $S$. aureus dermonecrotic model [46] [47]. Moreover, the efficiency of monoclonal antibodies seems to be additive or synergistic when administered along with clinically used antibiotics (vancomycin or linezolid) [45] [47], which suggests that the treatment by antibiotics along with antibodies will be more efficacious than either of them. A number of compounds or molecules which block the $\alpha$-hemolytic activity of $S$. aureus hemolysin have been discovered. Recent studies revealed that $\beta$-cyclodextrin derivative inhibits the $\alpha$-hemolysis in vitro and protects the host against $S$. aureus infection [48] [49] Insilico tools and simulation programs have enabled to find other inhibitors for $\alpha$-hemolysin [50] [51] [52] [53]. High throughput virtual screening of peptide or compound libraries facilitated to find potent inhibitors for the crystal structure of $\alpha$-hemolysin [54] [55]. The host receptor for $\alpha$-hemolysin, apparently the ADAM10, is an attractive target for the design of an inhibitor to block the toxin receptor interaction [56] and to reduce the lesions and the severity of recurrent skin and soft tissue infection [57] (Table 3).

\subsection{Beta Hemolysin}

\subsubsection{Discovery}

$\beta$-toxin is a non-pore forming hemolysin, a neutral sphingomyelinase secreted by the majority of $S$. aureus isolates and it was first identified by Glenny and Stevens in 1935 [60]. A $4 \mathrm{~kb}$ ClaIchromosomal fragment which encodes 330 amino acid polypeptide with an approximate molecular weight of 39,000 Daltons. A 200 residue region of homology (55.7\%) has been found with Bacillus cereus sphingomyelinase [61]. The $\mathrm{N}$-terminal sequence of secreted $\beta$-hemolysin is GluSerLysAspAspThrAspLeuLys corresponding to residues 35 - 44 [62]. Initial 34 residues of the polypeptide contain a signal sequence which gets cleaved upon secretion, resulting in a mature protein with a molecular weight 35,000 . Some studies have shown that $\beta$-hemolysin is extremely basic, with an isoelectric point above $\mathrm{pH}$ 9. $\beta$-toxin lyses erythrocytes mainly for its source of haem. It is highly active against sheep erythrocytes but not on rabbit erythrocytes [6].

\subsubsection{Chemical Nature of $\beta$-Hemolysin}

It is also called as hot-cold hemolysin due to the enhanced haemolytic activity observed below $10^{\circ} \mathrm{C}$ after incubation at $37^{\circ} \mathrm{C}$ overnight. It is also known as sphingomyelinase. So far three forms of sphingomyelinases have been identified based on the isoelectric $\mathrm{pH}$. One of them is acidic, the second one is neutral and the third one is alkaline. Staphylococcus aureus beta toxin is an $\mathrm{Mg}^{2+}$ dependent neutral sphingomyelinase that hydrolyzes sphingomyelin into phosphorylcholine and ceramide [ $\mathrm{N}$-acyl sphingosine]. The ceramide may have several roles to play in eukaryotic cells, including stimulation of second messenger system, activation of mitogen-activated protein kinases [MAPKs], changes in cell shape, and 
even apoptosis based on the length of the fatty acids or the mode of metabolism [63]. This toxin enhances the host cell susceptibility to other lytic agents such as $\alpha$-hemolysin \& PVL. Lymphocytes, keratinocytes and neutrophils are susceptible to beta toxin and the toxicity is enhanced by $\mathrm{Mg}^{2+}$. However, these cells are less sensitive than sheep erythrocytes due to the presence of less sphingomyelin [64] as susceptibility of various cell types is based on sphingomyelin content.

Table 3. $\alpha$-hemolysinin Drug Discovery/Therapeutic development.

\begin{tabular}{|c|c|c|c|c|}
\hline $\begin{array}{c}\text { Toxin/Therapeutic } \\
\text { target }\end{array}$ & $\begin{array}{l}\text { Type of inhibitor } \\
\text { and specifications }\end{array}$ & $\begin{array}{l}\text { Potential mechanism of } \\
\text { action }\end{array}$ & $\begin{array}{c}\text { Phase of } \\
\text { development }\end{array}$ & Ref \\
\hline & $\begin{array}{l}\text { Anti-Hla MAb } \\
\text { MAbs 7B8 \& 1A9 }\end{array}$ & $\begin{array}{l}\text { Antagonizes the toxin } \\
\text { activity and block the } \\
\text { formation of } \alpha \text {-hemolysin } \\
\text { oligomer on the target }\end{array}$ & $\begin{array}{l}\text { Mice pneumonia } \\
\text { model }\end{array}$ & {$[44]$} \\
\hline & $\begin{array}{l}\text { Anti-Hla MAb } \\
\text { High affinity MAb } \\
\text { 2A3.1 }\end{array}$ & $\begin{array}{l}\text { Inhibits toxin mediated } \\
\text { cell lysis by blocking the } \\
\text { formation of toxin heptamers } \\
\text { on erythrocyte membranes }\end{array}$ & $\begin{array}{l}\text { Independent } \\
\text { animal models, } \\
\text { S.aureus mouse } \\
\text { dermonecrotic } \\
\text { model and } \\
\text { pneumonia model }\end{array}$ & {$[45]$} \\
\hline & $\begin{array}{c}\text { MAb } \\
\text { MAb LTM14 }\end{array}$ & $\begin{array}{l}\text { Prevents the binding } \\
\text { of toxin to the plasma } \\
\text { membrane of susceptible } \\
\text { host cells }\end{array}$ & $\begin{array}{l}\text { Mice pneumonia, } \\
\text { skin and } \\
\text { bacteremia models }\end{array}$ & [47] \\
\hline & $\begin{array}{c}\text { Chemical } \\
\text { compound } \\
\text { ANBO } \beta \mathrm{CD} \\
\text { ( } \beta \text {-cyclodextrin } \\
\text { derivatives })\end{array}$ & $\begin{array}{l}\text { Blocks the trans membrane } \\
\text { pores and prevents the ion } \\
\text { leakage through the pores }\end{array}$ & $\begin{array}{l}\text { Mice pneumonia } \\
\text { model }\end{array}$ & [49] \\
\hline \multirow[t]{6}{*}{$a$-hemolysin } & $\begin{array}{l}\text { Chemical compound } \\
\text { Isatin-Schiff copper } \\
\text { (II) complexes }\end{array}$ & $\begin{array}{l}\text { Prevents the formation } \\
\text { of ion channels by } \\
\text { obstructing the constriction } \\
\text { region of the hemolysin } \\
\text { channel }\end{array}$ & In vitro assays & [52] \\
\hline & $\begin{array}{l}\text { Chemical compound } \\
\text { ADAM10 inhibitor } \\
\text { (GI254023X) }\end{array}$ & $\begin{array}{l}\text { Inhibits binding of } \\
\alpha \text {-hemolysin to its host } \\
\text { receptor (ADAM10) }\end{array}$ & $\begin{array}{l}\text { Mice model of } \\
\text { recurrent skin and } \\
\text { soft tissue infection }\end{array}$ & [57] \\
\hline & $\begin{array}{l}\text { Natural compound } \\
\text { Oroxylin A, Oroxin } \\
\text { A and Oroxin B }\end{array}$ & $\begin{array}{l}\text { Binds to the stem region of } \\
\alpha \text {-hemolysin and prevents } \\
\text { conformational transition of } \\
\text { toxin from monomer to } \\
\text { oligomer }\end{array}$ & In vitro assays & [51] \\
\hline & $\begin{array}{l}\text { Natural compound } \\
\text { Morin hydrate }\end{array}$ & $\begin{array}{l}\text { Inhibits self-assembly } \\
\text { of the heptameric } \\
\text { trans membrane pore of } \\
\quad \alpha \text {-hemolysin }\end{array}$ & $\begin{array}{l}\text { Mice pneumonia } \\
\text { model }\end{array}$ & [53] \\
\hline & $\begin{array}{l}\text { Natural compound } \\
\text { Curcumin }\end{array}$ & $\begin{array}{l}\text { Inhibits the } \\
\text { pore forming }\end{array}$ & $\begin{array}{l}\text { Mice pneumonia } \\
\text { model }\end{array}$ & [58] \\
\hline & $\begin{array}{l}\text { Natural compound } \\
\text { Baicalin }\end{array}$ & $\begin{array}{l}\text { Interrupts the } \\
\text { formation of heptamer }\end{array}$ & In vivo assays & [59] \\
\hline
\end{tabular}




\subsubsection{Mode of Action}

$\beta$-toxin structure is similar to that of sphingomyelinases produced by Listeria ivanovii, Leptospirainterrogans and Bacillus cereus [65]. Biological activities of $\beta$-toxin including hemolysis and lymphotoxicity are due to the sphingomyelinase activity of the enzyme. Its structure indicates that it belongs to the DNase I superfamily and is it possible that $\beta$-toxin might cleave DNA [66] (Figure 4).

\subsubsection{Pathophysiology}

Epidemiological studies showed that $\beta$-toxin plays a role in the recurrence of $S$. aureus furunculosis, chronic osteomyelitis and respiratory infections in humans [67] [68]. It also contributes to biofilm formation and this activity is independent of sphingomyelinase activity [69] Animal studies revealed that $\beta$-toxin is a virulence factor for $S$. aureus induced keratitis [67] and mastitis [70]. It reportedly causes neutrophil-mediated lung injury, through both its sphingomyelinase activity and syndecan-1 [66]. Purification of $\beta$-toxin includes gel-filtration, precipitation, ion-exchange chromatography, gel electrophoresis and isoelectric focusing [5] (Table 4).

\section{3. $\gamma$-Hemolysin}

\subsubsection{Discovery}

Gamma hemolysin was first described by Smith and Price in 1938. It is able to lyse erythrocytes from a wide range of mammalian species [72] like human, rabbit, and sheep though rabbit RBCs were more sensitive and those of fowl were most resistant. The gene encoding $\gamma$-hemolysin is quite ubiquitous in (>99.5\%) human isolates of $S$. aureus [73]. Staphylococcus aureus 5R is a good source of gamma hemolysin as it does not produce any other hemolysins [74].

\subsubsection{Chemical Nature of $\gamma$-Hemolysin}

$\gamma$-Hemolysin and Leukocidin are two component toxins located in two distinct loci within the $S$. aureus genome and a high level of sequence identity is present between these genes. The $\gamma$-hemolysin gene is located within a $4.5 \mathrm{~kb}$ ScaI fragment of $S$. aureus chromosome. It is another type of pore forming toxin, unlike $\alpha$-hemolysin [75]. The hlg consists of two transcription units, (the first one encodes gamma hemolysin-A ( $\mathrm{Hlg} \mathrm{A}$ ) like protein, a class $\mathrm{S}$ component, and the second one codes gamma hemolysin C ( $\mathrm{Hlg} \mathrm{C})$ \& gamma hemolysin B (Hlg B), a class of $\mathrm{F}$ and $\mathrm{S}$ components. These three proteins are translated as a single protein which is cleaved to form mature proteins which get secreted. Molecular weights of these proteins are 32,000 for $\mathrm{Hlg}$ A, 32,500 for $\mathrm{Hlg}$ C, 34,000 for $\mathrm{Hlg}$ B and their pI values are 9.4, 9.0, and 9.1 respectively [76].

Table 4. Drug discovery and development.

\begin{tabular}{cccccc}
\hline \multirow{2}{*}{$\begin{array}{c}\text { Toxin/ } \\
\text { Therapeutic target }\end{array}$} & Type & Compound & $\begin{array}{c}\text { Potential } \\
\text { mechanism of action }\end{array}$ & $\begin{array}{c}\text { Phase of } \\
\text { development }\end{array}$ & Ref \\
\cline { 2 - 5 }$\beta$-hemolysin & MAb & $\begin{array}{c}\text { dAb.6X his } \\
\text { clones }\end{array}$ & $\begin{array}{c}\text { Inhibits the beta-hemolysin } \\
\text { activity }\end{array}$ & In vitro & {$[71]$} \\
\hline
\end{tabular}




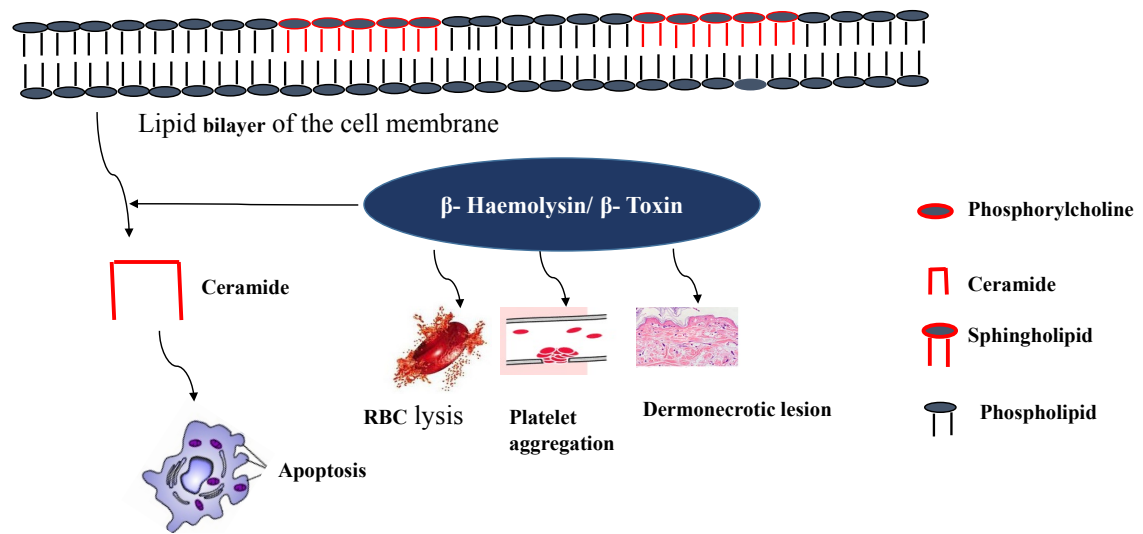

Figure 4. Interaction between $\beta$-toxin and cell membrane. Sphingomyelinase hydrolyzes the sphingomyelin into ceramides and phosphorylcholine.

\subsubsection{Mode of Action}

Like $\alpha$-hemolysin, $\gamma$-Hemolysin and Panton-Valentine Leukocidin (PVL or Luk SPV and LukFPV) are also membrane-bound hetero oligomers on the surface of target cells, creating barrel-like pores which lead to cell lysis [72]. Binding studies revealed both $\mathrm{S}$ and $\mathrm{F}$ components are necessary for the biological action, S-component binds first and recruits the F-component to the surface of phagocytic cells, which is followed by oligomerization and cell lysis [77]. Structure of these bi-component toxins and their mechanism of pore formation are extensively studied. Gamma hemolysin is not identifiable on blood agar plates due to the inhibitory effect of agar on the toxin activity [73]. Staphylococcus aureus reportedly expresses up to five different bi-component leukocidins which include $\gamma$-Hemolysin (HlgAB and HlgCB), Panton Valentine Leukocidin (PVL or LukSF), LukED and Luk GH [78] (Figure 5 and Figure 6).

\subsubsection{Pathophysiology}

Gammahemolys in is able to enhance the survival of $S$. aureus in human blood [80]. Ex vivo findings revealed that $S$. aureus $\gamma$-hemolysin is associated with blood stream infections including bacteremia and septic arthritis in mouse models [35] [80] and endophthalmitis in rabbits [81]. It also plays a role in the pathogenesis of toxic shock syndrome (TSS) [82]. Gamma-hemolysin has been shown to be dermonecrotic in rabbits [83] (Table 5).

Table 5. Drug discovery and development of therapy.

\begin{tabular}{|c|c|c|c|c|c|}
\hline $\begin{array}{c}\text { Toxin/Therapeutic } \\
\text { target }\end{array}$ & Type & Compound & $\begin{array}{l}\text { Potential mechanism } \\
\text { of action }\end{array}$ & $\begin{array}{c}\text { Phase of } \\
\text { development }\end{array}$ & Ref \\
\hline \multirow[b]{2}{*}{$\gamma$-hemolysin } & $\begin{array}{l}\text { Natural } \\
\text { compound }\end{array}$ & Ponciretin & $\begin{array}{l}\text { Inhibits the hemolytic } \\
\text { and cytolytic activity } \\
\text { of the toxin }\end{array}$ & $\begin{array}{c}\text { Docking } \\
\text { agent }\end{array}$ & [84] \\
\hline & $\begin{array}{l}\text { Natural } \\
\text { compound }\end{array}$ & $\begin{array}{c}\text { Garcinia } \\
\text { pedunculta \& } \\
\text { 1,3,6,7-tetra } \\
\text { hydroxyxanthone }\end{array}$ & $\begin{array}{l}\text { Inhibits the hemolytic } \\
\text { and cytolytic activity } \\
\text { of the toxin }\end{array}$ & $\begin{array}{c}\text { Docking } \\
\text { agent }\end{array}$ & [85] \\
\hline
\end{tabular}




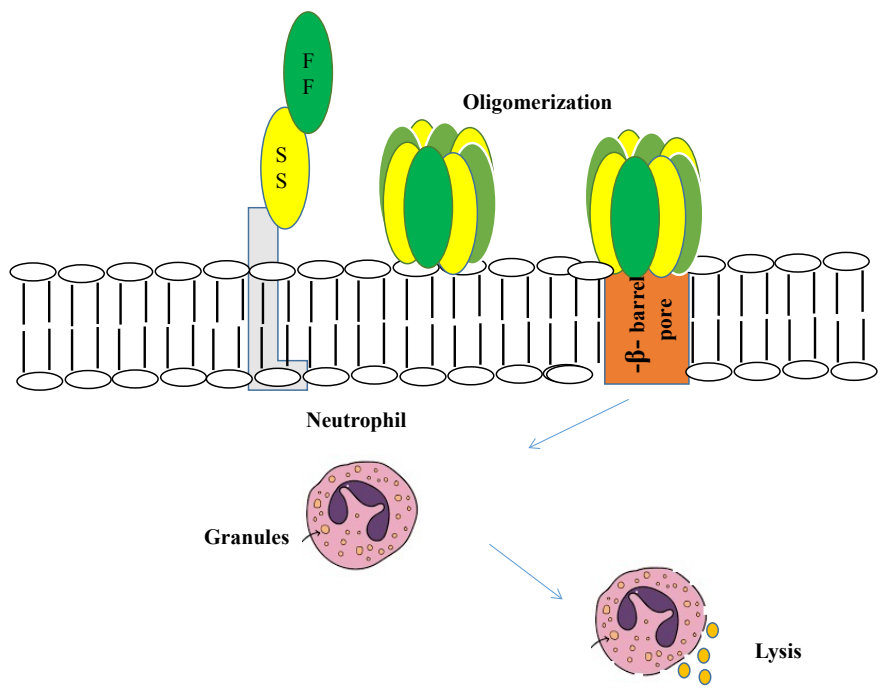

Figure 5. Interaction between $\gamma$-hemolysin and cell membrane. $S$. aureus produces the bi-component $\gamma$-toxin as two sub units (green and yellow) which bind to the receptor, oligomerize and create pores in the membrane leading to cell lysis.

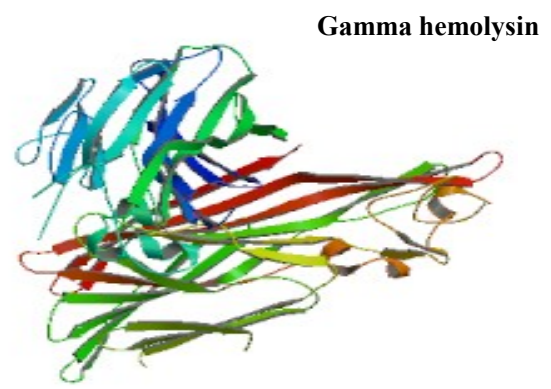

Figure 6. Structure of Gamma-hemolysin (PDB ID: 2QK7) [79].

\subsection{Panton-Valentine Leukocidin (PVL)}

Panton-Valentine Leukocidin is extracellular cytotoxin and it was first described by Van de Velde in 1894 and it was first purified by Woddin from $S$. aureus V8 culture supernatants [86]. Human and rabbit neutrophils are highly sensitive to PVL [87] and this gene spreads among $S$. aureus due to a combination of clonal expansion and horizontal transfer [88]. It contains two synergistic but separate protein components ( $32 \mathrm{kDa}$ and $38 \mathrm{kDa}$ ) named as " $\mathrm{S}$ " slow eluted and "F" fast eluted on the basis of their migration on carboxy methyl cellulose columns [89]. It forms pores in the membranes of leukocytes and leads to lysis. The genes of lukF-PV and lukS-PV have been recently cloned and sequenced [90]. It mainly targets the polymorphonuclear cells [91].

Panton \& Valentine first revealed in 1932 that this leukotoxin was associated with skin and soft tissue infection [86]. Association between PVL positive $S$. aureus isolates and community-acquired (CA) pneumonia was reported by Lina et al., through PCR assay [92], and these studies were later correlated with studies conducted in France, Sweden, Netherlands and the United Kingdom [93] [94] [95] [96]. PVL is highly prevalent among CA-MRSA strains world wide. Studies 
revealed that $98 \%$ of CA-MRSA isolates were positive for the PVL gene [97] and is considered as a marker for the detection of CA MRSA isolates worldwide [92] [98]. Clinical studies propose that PVL is a crucial virulence factor in necrotizing disease [92] [99].

\subsection{Delta-Hemolysin (Hld)}

Williams and Harper in 1947 detected for the first time delta hemolysin activity in sheep blood agar plates wherein alpha and beta hemolysins were inhibited by respective antibodies [100]. Delta-hemolysin is a small amphipathic peptide toxin consisting of 26 amino acids, produced by almost all isolates (97\%) of $S$. aureus. Molecular weight of this protein is approximately 3000 daltons [101] and it is secreted without signal peptide. A variety of activities have been attributed to delta hemolysin. Its activity is not inhibited by ethylene diamine tetra acetic acid, citrate or metal cations while it is uniquely inhibited by serum components, possibly the serum proteins or phospholipids [100]. The toxin acts as a surfactant to disrupt the cell membrane resulting in membrane damage in a variety of mammalian cells, as well as membrane-bound organelles [101]. The toxin lyses the cell by three different mechanisms: first, it binds and forms transmembrane pores, next it destabilizes the membrane and at high concentrations, it acts as a detergent that dissolves the membrane [102].

A 514-nucleotide transcript is encoded by the hld gene located within the RNAIII locus of accessory gene regulator (agr) which controls the expression of virulence factor [7]. Delta hemolysin is controlled by agr and maximum expression is found in post exponential phase. This hemolysin causes a rapid influx of $\mathrm{Ca}^{2+}$ and stimulates free radicals production in human granulocytes [101]. Among the hemolysins produced by $S$. aureus, delta hemolysin activity seems to be accentuated (enhanced) by $\beta$-hemolysin [103].

Delta hemolysin activates neutrophils which lead to the generation of Reactive Oxygen Intermediates (ROI) and platelet activating factor, inducing the release of granule enzymes and modulating leukotriene generation [104]. Delta hemolysin has a significant role in the development of skin disease, atopic dermatitis, due to mast cell degranulation [104]. It also induces the release of pro-inflammatory cytokines from keratinocytes [14]. It is transcribed from a promoter immediately upstream of the agr locus, and which is positively controlled by agr-QS system. Production of delta hemolysin can be used as a surrogate marker of agr function [105] [106]. Recent studies revealed that agr function can be assessed by the evaluation of delta toxin production from whole bacterial cells using whole cell matrix-assisted laser desorption ionization time of flight (MALDI-TOF) mass spectrometry [107].

\section{Accessory Gene Regulator (AGR) Quorum Sensing (QS) System}

Staphylococcal agr-QS system is a well-studied central transcriptional regulator for controlling the expression of staphylococcal virulence factors including the 
hemolysins, such as $\alpha, \beta, \gamma$ and $\delta$-hemolysins. It is encoded by the agr locus which consists of two transcription units driven by P2 \& P3. P2 operon encodes RNA II, consists of four proteins to activate the QS system, of which Agr C is the receptor for auto inducing peptide (AIP) and Agr A is the response regulator to activate the transcription of $\mathrm{P} 2 \& \mathrm{P} 3$ and two membrane proteins, Agr B and Agr D which combine to produce and secrete an Auto Inducing Peptide (AIP). The agr $\mathrm{P} 3$ promoter drives the synthesis of RNA III, the major regulator of agr QS system [7]. Part of the RNA III encodes the hld, and therefore the expression of hld serves as a surrogate marker to assess agr functionality (Figure 7).

\section{Methods for Detecting Hemolysins}

\subsection{Qualitative Methods}

It was reported in a classical study of $S$. aureus from human clinical isolates [4] that $96 \%$ produced $\alpha$-hemolysin, $11 \%$ produced $\beta$-hemolysin and $97 \%$ produced $\delta$-hemolysin though $\gamma$-hemolysin was not reported (probably due to inhibition by agar). Hemolysins $\alpha$ and $\delta$ are more common among human isolates while $\beta$ hemolysin is detected in addition to these two, in animal isolates of $S$. aureus. Clinical isolates are cultured on blood agar plates using Columbia blood agar powder Supplemented with rabbit erythrocytes ( $\alpha$-hemolysin), sheep erythrocytes ( $\beta$-hemolysins) are used for the detection of $\alpha \& \beta$ hemolytic activity [108]. $\gamma$-hemolysin activity is determined on rabbit blood in agarose plate instead of agar plate as agar inhibits the $\gamma$-hemolysin activity [109]. Delta hemolysin activity is detected and semi-quantitated by cross-streaking of test isolate perpendicular to $S$. aureus 25923. The latter is a reference strain which produces only $\beta$-hemolysin on sheep blood agar plates. A zone of enhanced hemolysis is seen at the junctions where $\beta \& \delta$ lysis zones overlap [110]. Original results of a representative experiment demonstrating various hemolysin activities on blood agar plates are presented from our laboratory (Figure 8).

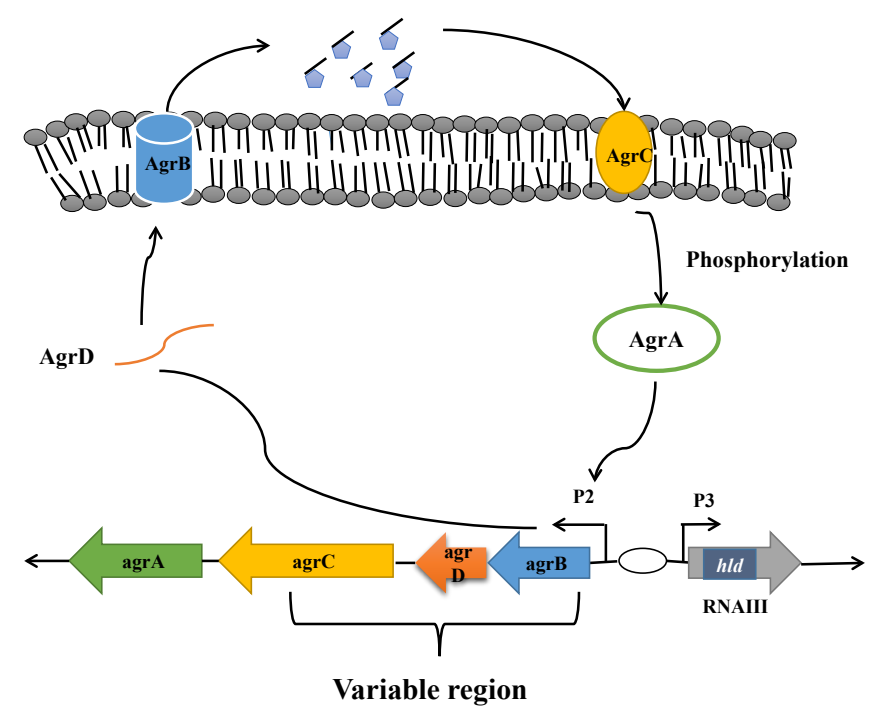

Figure 7. $\operatorname{Agr} \mathrm{QS}$ system. 


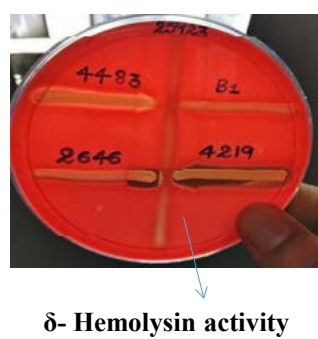

(a)

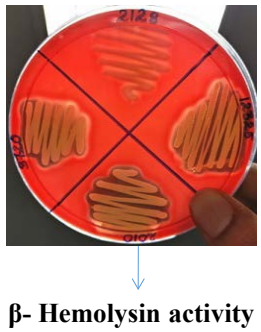

(b)

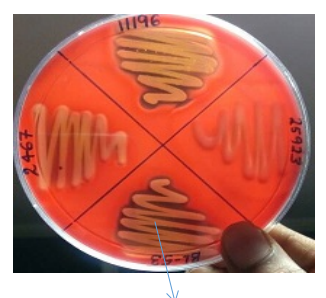

$\alpha$ - Hemolysin activity

(c)

Figure 8. Hemolytic activities of $S$. aureus on Sheep blood agar plate: (a) $\delta$-hemolysin activity on Sheep blood agar plate (b) $\beta$-hemolysin activity on Sheep blood agar plate (c) $\alpha$-hemolysin activity on Rabbit blood agar plate (data from our laboratory).

\subsection{Genotypic Methods for Detection of Hemolysins}

Hemolysin genotyping is done using specific oligo primers to amplify target sequences by PCR from the $h l a, h l b, h l g$, hld genes which encode the hemolysins alpha, beta, gamma and delta respectively in $S$. aureus [108].

\subsection{Quantitative Methods}

\subsection{1. $\alpha$-Hemolysin Assay}

Functional assay is used to measure the hemoglobin released from the rabbit erythrocytes by the hemolytic activity of $\alpha$-hemolysin [111]. Briefly, rabbit erythrocytes were centrifuged and washed three times with PBS and diluted to a concentration of $10^{7}$ cells per ml. Rabbit erythrocytes $\left(10^{7}\right)$ were added to the $\alpha$-toxin that was serially diluted two fold in micro titer plate and incubated at $37^{\circ} \mathrm{C}$ until the erythrocytes in the control lacking alpha toxin had settled. The highest dilution producing red blood cell lysis was considered the end point [49].

\subsubsection{Beta-Hemolysis Assay}

$\beta$-hemolysinis measured by spectrophotometer as sphingomyelinase activity and the amount of cleavage of phospholipid into sphingomyelin and phosphorylcholine is determined [67].

\subsubsection{Real Time PCR}

Quantitative real time reverse transcription PCR (qRTPCR) is used to measure the transcripts of hla \& hld in $S$. aureus isolates and $g y r \mathrm{~B}$ is used as a normalizer for hld [110], in case of alpha hemolysin 16S rRNA gene was used as internal or reference control [112].

\section{Conclusion}

Hemolysins play an important role in pathogenesis of all diseases due to $S$. aureus. They help to lyse the host cell membrane, maim or evade the immune system, release the nutrients for the pathogen's survival and progression of disease. Since $S$. aureus has become a super bug resistant to all available antibiotic, it is imperative that alternate targets are identified and drugs designed. Conventional 
antibiotics target the nucleic acid and protein biosynthesis in the microorganisms and it became inevitable for the microbe to protect itself and survive which led to the development of resistance through several mechanisms. Virulence factors like hemolysins offer attractive targets for anti-virulence drug development and the chances of resistance to such anti-virulence drugs/therapeutics are very low as such drugs do not threaten the survival of the microbe As there are no new antibiotics under approval stage in any country, it is imperative that efforts are maintained to identify new targets and develop new drugs which would either limit the growth of these super bugs or at least reduce the severity of such infections through anti-virulence drugs. This review attempted to highlight the importance of hemolysins of $S$. aureus from the host as well as pathogen perspective and as potential targets for new drug development to be used as adjunct anti-virulence therapeutics or quorum quenchers to inhibit biofilm formation. Many laboratories including ours are working on the hemolysin profile of clinical isolates of $S$. aureus and to identify compounds either from natural products or through synthetic routes which would either inhibit the hemolysin synthesis or down regulate the agr system to effect quorum quenching. Though there are reports of several promising candidate drugs with high potential as anti-virulence drugs or as inhibitors of biofilm, none of them have been approved for clinical use yet.

\section{Conflicts of Interest}

The authors declare no conflicts of interest regarding the publication of this paper.

\section{References}

[1] David, M.Z. and Daum, R.S. (2010) Community-Associated Methicillin-Resistant Staphylococcus aureus. Epidemiology and Clinical Consequences of an Emerging Epidemic. Clinical Microbiology Reviews, 23, 616-687. https://doi.org/10.1128/CMR.00081-09

[2] Vasconcelos, N.G. and Cunha, M.L.R.S. (2010) Staphylococcal Enterotoxins: Molecular Aspects and Detection Methods. Journal of Public Health and Epidemiology, 2, 29-42.

[3] Kaneko, J. and Kamio, Y. (2004) Bacterial Two-Component and Hetero-Heptameric Pore-Forming Cytolytic Toxins: Structures, Pore-Forming Mechanism, and Organization of the Genes. Bioscience, Biotechnology, and Biochemistry, 68, 981-1003. https://doi.org/10.1271/bbb.68.981

[4] Wiseman, G.M. (1975) The Hemolysins of Staphylococcus aureus. Bacteriological Reviews, 39, 317-344. https://www.ncbi.nlm.nih.gov/pmc/PMC408339/

[5] Dinges, M.M., Orwin, P.M. and Schlievert, P.M. (2000) Exotoxins of Staphylococcus aureus. Clinical Microbiology Reviews, 13, 16-34. https://doi.org/10.1128/CMR.13.1.16

[6] Larsen, H.D., Aarestrup, F.M. Jensen. N.E. (2002) Geographical Variation in the Presence of Genes Encoding Superantigenic Exotoxins and $\beta$-Hemolysin among Staphylococcus aureus Isolated from Bovine Mastitis in Europe and USA. Veteri- 
nary Microbiology, 85, 61-67. https://doi.org/10.1016/S0378-1135(01)00478-3

[7] Novick, R.P. (2003) Autoinduction and Signal Transduction in the Regulation of Staphylococcal Virulence. Molecular Microbiology, 48, 1429-1449. https://doi.org/10.1046/j.1365-2958.2003.03526.x

[8] Lowy, F.D. (1998) Staphylococcus aureus Infections. The New England Journal of Medicine, 339, 520-532. https://doi.org/10.1056/NEJM199808203390806

[9] Watkins, R.R., David, M.Z. and Salata, R.A. (2012) Current Concepts on the Virulence Mechanisms of Meticillin-Resistant Staphylococcus aureus. Journal of Medical Microbiology, 61, 1179-1193. https://doi.org/10.1099/jmm.0.043513-0

[10] Becker, K., Heilmann, C. and Peters, G. (2014) Coagulase-Negative Staphylococci. Clinical Microbiology Reviews, 27, 870-926. https://doi.org/10.1128/CMR.00109-13

[11] Löfblom, J., Rosenstein, R., Nguyen, M.-T., Ståhl, S. and Götz, F. (2017) Staphylococcus carnosus. From Starter Culture to Protein Engineering Platform. Applied Microbiology and Biotechnology, 101, 8293-8307. https://doi.org/10.1007/s00253-017-8528-6

[12] Pinheiro, L., Brito, C.I., de Oliveira, A., Martins, P.Y.F., Pereira, V.C. and da Cunha, M.D.L.R.D.S. (2015) Staphylococcus epidermidis and Staphylococcus haemolyticus. Molecular Detection of Cytotoxin and Enterotoxin Genes. Toxins, 7, 3688-3699. https://doi.org/10.3390/toxins7093688

[13] Casanova, C., Iselin, L., von Steiger, N., Droz, S. and Sendi, P. (2011) Staphylococcus hyicus Bacteremia in a Farmer. Journal of Clinical Microbiology, 49, 4377-4378. https://doi.org/10.1128/JCM.05645-11

[14] Böcher, S., Tønning, B., Skov, R.L. and Prag, J. (2009) Staphylococcus lugdunensis, a Common Cause of Skin and Soft Tissue Infections in the Community. Journal of Clinical Microbiology, 47, 946-950. https://doi.org/10.1128/JCM.01024-08

[15] Rozalska, M., Derczynska, A. and Maszewska, A. (2015) Synergistic Hemolysins of Coagulase-Negative Staphylococci (CoNS). Acta Biochimica Polonica, 62, 757-764. https://doi.org/10.18388/abp.2015_1126

[16] Kuroda, M., Yamashita, A., Hirakawa, H., Kumano, M., Morikawa, K., Higashide, M., et al. (2005) Whole Genome Sequence of Staphylococcus saprophyticus Reveals the Pathogenesis of Uncomplicated Urinary Tract Infection. Proceedings of the National Academy of Sciences of the United States of America, 102, 13272-13277. https://doi.org/10.1073/pnas.0502950102

[17] Stepanović, S., Vuković, D., Trajković, V., Samardžić, T., Cupić, M. and ŠvabićVlahović, M. (2001) Possible Virulence Factors of Staphylococcus sciuri. FEMS Microbiology Letters, 199, 47-53. https://doi.org/10.1111/j.1574-6968.2001.tb10649.x

[18] Hébert, G.A. and Hancock, G.A. (1985) Synergistic Hemolysis Exhibited by Species of Staphylococci. Journal of Clinical Microbiology, 22, 409-415.

[19] Al-Saffar, A.K., Al-daan, W.T. and Ali, S.A. (2016) Effect of Piper Cubeba Fruits Extract on Hemolysin Production of E. Coli Isolated from Urinary Tract Infection. International Journal of Chem Tech Research, 9, 476-482.

[20] Ristow, L.C. and Welch, R.A. (2016) Hemolysin of Uropathogenic Escherichia coli: A Cloak or a Dagger? Biochimica et Biophysica Acta, 1858, 538-545. https://doi.org/10.1016/j.bbamem.2015.08.015

[21] Epple, H.J., Mankertz, J., Ignatius, R., Liesenfeld, O., Fromm, M., Zeitz, M., et al. (2004) Aeromonas hydrophila $\beta$-Hemolysin Induces Active Chloride Secretion in Colon Epithelial Cells (HT-29/B6). Infection and Immunity, 72, 4848-4858. 
https://doi.org/10.1128/IAI.72.8.4848-4858.2004

[22] Glomski, I.J., Gedde, M.M., Tsang, A.W., Swanson, J.A. and Portnoy, D.A. (2002) The Listeria monocytogenes Hemolysin Has an Acidic pH Optimum to Compartmentalize Activity and Prevent Damage to Infected Host Cells. The Journal of Cell Biology, 156, 1029-1038. https://doi.org/10.1083/jcb.200201081

[23] Hirst, R.A., Kadioglu, A., O'Callaghan, C. and Andrew, P.W. (2004) The Role of Pneumolysin in Pneumococcal Pneumonia and Meningitis. Clinical \& Experimental Immunology, 138, 195-201. https://doi.org/10.1111/j.1365-2249.2004.02611.x

[24] Moonah, S., Sanders, N.G., Persichetti, J.K. and Sullivan Jr., D.J. (2004) Erythrocyte Lysis and Xenopus Laevis Oocyte Rupture by Recombinant Plasmodium falciparum hemolysin III. Eukaryotic Cell, 13, 1337-1345. https://doi.org/10.1128/EC.00088-14

[25] Lee, S.H., Kim, S., Park, S.C. and Kim, M.J. (2002) Cytotoxic Activities of Leptospira interrogans Hemolysin SphH as a Pore-Forming Protein on Mammalian Cells. Infection and Immunity, 70, 315-322. https://doi.org/10.1128/IAI.70.1.315-322.2002

[26] Oda, M., Takahashi, M., Matsuno, T., Uoo, K., Nagahama, M. and Sakurai, J. (2010) Hemolysis Induced by Bacillus cereus Sphingomyelinase. Biochimica et Biophysica Acta, 1798, 1073-1080. https://doi.org/10.1016/j.bbamem.2010.03.004

[27] Morikawa, K., Takemura, A.J., Inose, Y., Tsai, M., Nguyen Thi, L.T., Ohta, T., et al. (2012) Expression of a Cryptic Secondary Sigma Factor Gene Unveils Natural Competence for DNA Transformation in Staphylococcus aureus. PLoS Pathogens, 8, e1003003. https://doi.org/10.1371/journal.ppat.1003003

[28] Bhakdi, S. and Tranum-Jensen, J. (1991) Alpha-Toxin of Staphylococcus aureus. Microbiological Reviews, 155, 733-751.

[29] Burnet, F. (1929) The Exotoxins of Staphylococcus pyogenes aureus. The Journal of Pathology and Bacteriology, 32, 717-734. https://doi.org/10.1002/path.1700320402

[30] Pattee, P.A. (1986) Chromosomal Map Location of the $\alpha$-Hemolysin Structural Gene in Staphylococcus aureus NCTC 8325. Infection and Immunity, 54, 593-596.

[31] Berube, B.J. and Bubeck Wardenburg, J. (2013) Staphylococcus aureus $\alpha$-Toxin: Nearly a Century of Intrigue. Toxins, 5, 1140-1166. https://doi.org/10.3390/toxins5061140

[32] Bubeck Wardenburg, J., Patel, R.J. and Schneewind, O. (2007) Surface Proteins and Exotoxins Are Required for the Pathogenesis of Staphylococcus aureus Pneumonia. Infection and Immunity, 75, 1040-1044. https://doi.org/10.1128/IAI.01313-06

[33] Kielian, T., Cheung, A. and Hickey, W.F. (2001) Diminished Virulence of an $\alpha$-Toxin Mutant of Staphylococcus aureus in Experimental Brain Abscesses. Infection and Immunity, 69, 6902-6911. https://doi.org/10.1128/IAI.69.11.6902-6911.2001

[34] Hume, E.B., Dajcs, J.J., Moreau, J.M. and O'Callaghan, R.J. (2000) Immunization with $\alpha$-Toxin Toxoid Protects the Cornea against Tissue Damage during Experimental Staphylococcus aureus Keratitis. Infection and Immunity, 68, 6052-6055. https://doi.org/10.1128/IAI.68.10.6052-6055.2000

[35] Nilsson, I.M., Hartford, O., Foster, T. and Tarkowski, A. (1999) $\alpha$-Toxin and Gamma-Toxin Jointly Promote Staphylococcus aureus Virulence in Murine Septic Arthritis. Infection and Immunity, 6, 1045-1049.

[36] Tobkes, N., Wallace, B.A. and Bayley, H. (1985) Secondary Structure and Assembly Mechanism of an Oligomeric Channel Protein. Biochemistry, 24, 1915-1920. https://doi.org/10.1021/bi00329a017

[37] Bhakdi, S., Muhly, M., Korom, S. and Hugo, F. (1989) Release of Interleukin-1 $\beta$ 
Associated with Potent Cytocidal Action of Staphylococcal $\alpha$-Toxin on Human Monocytes. Infection and Immunity, 57, 3512-3519.

[38] Wilke, G.A. and Bubeck Wardenburg, J. (2010) Role of a Disintegrin and Metalloprotease 10 in Staphylococcus aureus $\alpha$-Hemolysin-Mediated Cellular Injury. Proceedings of the National Academy of Sciences of the United States of America, 107, 13473-13478. https://doi.org/10.1073/pnas.1001815107

[39] Hildebrand, A., Pohl, M. and Bhakdi, S. (1991) Staphylococcus aureus $\alpha$-Toxin. Dual Mechanism of Binding to Target Cells. The Journal of Biological Chemistry, 266, 17195-17200.

[40] Liang, X. and Ji, Y. (2007) Involvement of $\alpha 5 \beta 1$-Integrin and TNF- $\alpha$ in Staphylococcus aureus $\alpha$-Toxin-Induced Death of Epithelial Cells. Cellular Microbiology, 9, 1809-1821. https://doi.org/10.1111/j.1462-5822.2007.00917.x

[41] Bubeck Wardenburg, J., Bae, T., Otto, M., Deleo, F.R. and Schneewind, O. (2007) Poring over Pores: $\alpha$-Hemolysin and Panton-Valentine Leukocidin in Staphylococcus aureus Pneumonia. Nature Medicine, 13, 1405-1406. https://doi.org/10.1038/nm1207-1405

[42] Schubert, S., Schwertz, H., Weyrich, A.S., Franks, Z.G., Lindemann, S., Otto, M., et al. (2011) Staphylococcus aureus $\alpha$-Toxin Triggers the Synthesis of B-Cell Lymphoma 3 by Human Platelets. Toxins, 3, 120-133.

https://doi.org/10.3390/toxins3020120

[43] Recsei, P., Kreiswirth, B., O’Reilly, M., Schlievert, P., Gruss, A. and Novick, R.P. (1986) Regulation of Exoprotein Gene Expression in Staphylococcus aureus by agar. Molecular Genetics and Genomics, 202, 58-61. https://doi.org/10.1007/BF00330517

[44] Ragle, B.E. and Bubeck Wardenburg, J. (2009) Anti- $\alpha$-Hemolysin Monoclonal Antibodies Mediate Protection against Staphylococcus aureus Pneumonia. Infection and Immunity, 77, 2712-2718. https://doi.org/10.1128/IAI.00115-09

[45] Hua, L., Hilliard, J.J., Shi, Y., Tkaczyk, C., Cheng, L., Yu, X., et al. (2014) Assessment of an Anti- $\alpha$-Toxin Monoclonal Antibody for Prevention and Treatment of Staphylococcus aureus-Induced Pneumonia. Antimicrobial Agents and Chemotherapy, 58, 1108-1117. https://doi.org/10.1128/AAC.02190-13

[46] Tkaczyk, C., Hua, L., Varkey, R., Shi, Y., Dettinger, L., Woods, R., et al. (2012) Identification of Anti- $\alpha$ Toxin Monoclonal Antibodies that Reduce the Severity of Staphylococcus aureus Dermonecrosis and Exhibit a Correlation between Affinity and Potency. Clinical and Vaccine Immunology, 19, 377-385. https://doi.org/10.1128/CVI.05589-11

[47] Foletti, D., Strop, P., Shaughnessy, L., Hasa-Moreno, A., Casas, M.G., Russell, M., et al. (2013) Mechanism of Action and in Vivo Efficacy of a Human-Derived Antibody against Staphylococcus aureus $\alpha$-Hemolysin. Journal of Molecular Biology, 425, 1641-1654. https://doi.org/10.1016/j.jmb.2013.02.008

[48] McCormick, C.C., Caballero, A.R., Balzli, C.L., Tang, A. and O'Callaghan, R.J. (2009) Chemical Inhibition of $\alpha$-Toxin, a Key Corneal Virulence Factor of Staphylococcus aureus. Investigative Ophthalmology \& Visual Science, 50, 2848-2854. https://doi.org/10.1167/iovs.08-3157

[49] Ragle, B.E., Karginov, V.A. and Bubeck Wardenburg, J. (2010) Prevention and Treatment of Staphylococcus aureus Pneumonia with a $\beta$-Cyclodextrin Derivative. Antimicrobial Agents and Chemotherapy, 54, 298-304.

https://doi.org/10.1128/AAC.00973-09

[50] Dong, J., Qiu, J., Zhang, Y., Lu, C., Dai, X., Wang, J., et al. (2013) Oroxylin A Inhibits Hemolysis via Hindering the Self-Assembly of $\alpha$-Hemolysin Heptameric 
Transmembrane Pore. PLOS Computational Biology, 9, e1002869. https://doi.org/10.1371/journal.pcbi.1002869

[51] Qiu, J., Wang, D., Zhang, Y., Dong, J., Wang, J. and Niu, X. (2013) Molecular Modeling Reveals the Novel Inhibition Mechanism and Binding Mode of Three Natural Compounds to Staphylococcal $\alpha$-Hemolysin. PLOS ONE, 8, e80197. https://doi.org/10.1371/journal.pone.0080197

[52] Melo, M.C., Teixeira, L.R., Pol-Fachin, L. and Rodrigues, C.G. (2016) Inhibition of the Hemolytic Activity Caused by Staphylococcus aureus $\alpha$-Hemolysin through Isatin-Schiff Copper (II) Complexes. FEMS Microbiology Letters, 363, fnv207. https://doi.org/10.1093/femsle/fnv207

[53] Wang, J., Zhou, X., Liu, S., Li, G., Shi, L., Dong, J., et al. (2015) Morin Hydrate Attenuates Staphylococcus aureus Virulence by Inhibiting the Self-Assembly of $\alpha$-Hemolysin. Journal of Applied Microbiology, 118, 753-763. https://doi.org/10.1111/jam.12743

[54] Rashidieh, B., Etemadiafshar, S., Memari, G., Mirzaeichegeni, M., Yazdi, S., Farsimadan, F., et al. (2015) A Molecular Modeling Based Screening for Potential Inhibitors to $\alpha$ Hemolysin from Staphylococcus aureus. Bioinformation, 11, 373-377. https://doi.org/10.6026/97320630011373

[55] Rani, N., Vijayakumar, S., Ptv, L. and Arunachalam, A. (2014) Inhibition of Pore Formation by Blocking the Assembly of Staphylococcus aureus $\alpha$-Hemolysin Through a Novel Peptide Inhibitor: An in Silco Approach. International Journal of Peptide Research and Therapeutics, 20, 575-583.

https://doi.org/10.1007/s10989-014-9424-x

[56] Dreymueller, D., Uhlig, S. and Ludwig, A. (2015) ADAM-Family Metalloproteinases in Lung Inflammation: Potential Therapeutic Targets. American Journal of Physiology-Lung Cellular and Molecular Physiology, 308, L325-L343. https://doi.org/10.1152/ajplung.00294.2014

[57] Sampedro, G.R., DeDent, A.C., Becker, R.E., Berube, B.J., Gebhardt, M.J., Cao, H., et al. (2014) Targeting Staphylococcus aureus $\alpha$-Toxin as a Novel Approach to Reduce Severity of Recurrent Skin and Soft-Tissue Infections. The Journal of Infectious Diseases, 210, 1012-1018. https://doi.org/10.1093/infdis/jiu223

[58] Wang, J., Zhou, X., Li, W., Deng, X., Deng, Y. and Niu, X. (2016) Curcumin Protects Mice from Staphylococcus aureus Pneumonia by Interfering with the Self-Assembly Process of $\alpha$-Hemolysin. Scientific Reports, 6, Article No. 28254. https://doi.org/10.1038/srep28254

[59] Qiu, J., Niu, X., Dong, J., Wang, D., Wang, J., Li, H., et al. (2012) Baicalin Protects Mice from Staphylococcus aureus Pneumonia via Inhibition of the Cytolytic Activity of $\alpha$-Hemolysin. The Journal of Infectious Diseases, 206, 292-301. https://doi.org/10.1093/infdis/jis336

[60] Glenny, A.T. and Stevens, M.F. (1935) Staphylococcus Toxins and Antitoxins. The Journal of Pathology, 40, 201-210. https://doi.org/10.1002/path.1700400202

[61] Yamada, A., Tsukagoshi, N., Udaka, S., Sasaki, T., Makino, S., Nakamura, S., et al. (1988) Nucleotide Sequence and Expression in Escherichia coli of the Gene Coding for Sphingomyelinase of Bacillus cereus. European Journal of Biochemistry, 175, 213-220. https://doi.org/10.1111/j.1432-1033.1988.tb14186.x

[62] Projan, S.J., Kornblum, J., Kreiswirth, B., Moghazeh, S.L., Eisner, W. and Novick, R.P. (1989) Nucleotide Sequence: The $\beta$-Hemolysin Gene of Staphylococcus aureus. Nucleic Acids Research, 17, 3305. https://doi.org/10.1093/nar/17.8.3305

[63] Futerman, A.H. and Hannun, Y.A. (2004) The Complex Life of Simple Sphingoli- 
pids. EMBO Reports, 5, 777-782. https://doi.org/10.1038/sj.embor.7400208

[64] Marshall, M.J., Bohach, G.A. and Boehm, D.F. (2000) Characterization of Staphylococcus aureus $\beta$-Toxin Induced Leukotoxicity. Journal of Natural Toxins, 9, 125-138.

[65] Goni, F.M. and Alonso, A. (2002) Sphingomyelinases: Enzymology and Membrane Activity. FEBS Letters, 531, 38-46. https://doi.org/10.1016/S0014-5793(02)03482-8

[66] Huseby, M., Shi, K., Brown, C.K., Digre, J., Mengistu, F., Seo, K.S., et al. (2007) Structure and Biological Activities of $\beta$ Toxin from Staphylococcus aureus. Journal of Bacteriology, 189, 8719-8726. https://doi.org/10.1128/JB.00741-07

[67] O’Callaghan, R.J., Callegan, M.C., Moreau, J.M., Green, L.C., Foster, T.J., Hartford, O.M., et al. (1997) Specific Roles of $\beta$-Toxin and $\beta$-Toxin during Staphylococcus aureus Corneal Infection. Infection and Immunity, 65, 1571-1578.

[68] Hedstrom, S.A. and Malmqvist, T. (1982) Sphingomyelinase activity of Staphylococcus aureus Strains from Recurrent Furunculosis and Other Infections. Acta Pathologica Microbiologica Scandinavica Series B: Microbiology, 90B, 217-220. https://doi.org/10.1111/j.1699-0463.1982.tb00108.x

[69] Huseby, M.J., Kruse, A.C., Digre, J., Kohler, P.L., Vocke, J.A., Mann, E.E., et al. (2010) $\beta$ Toxin Catalyzes Formation of Nucleoprotein Matrix in Staphylococcal Biofilms. Proceedings of the National Academy of Sciences of the United States of America, 107, 14407-14412. https://doi.org/10.1073/pnas.0911032107

[70] Bramley, A.J., Patel, A.H., O’Reilly, M., Foster, R. and Foster, T.J. (1989) Roles of $\alpha$-Toxin and $\beta$-Toxin in Virulence of Staphylococcus aureus for the Mouse Mammary Gland. Infection and Immunity, 57, 2489-2494.

[71] Jangra, P. and Singh, A. (2010) Staphylococcus aureus $\beta$-Hemolysin-Neutralizing Single-Domain Antibody Isolated from Phage Display Library of Indian Desert Camel. Asian Pacific Journal of Tropical Medicine, 3, 1-7. https://doi.org/10.1016/S1995-7645(10)60020-X

[72] Smith, M.P. (1938) Staphylococcus $\gamma$-Haemolysin. The Journal of Pathology, 47, 379-393. https://doi.org/10.1002/path.1700470303

[73] Prevost, G., Couppie, P., Prevost, P., Gayet, S., Petiau, P., Cribier, B., et al. (1995) Epidemiological Data on Staphylococcus aureus Strains Producing Synergohymenotropic Toxins. Journal of Medical Microbiology, 42, 237-245. https://doi.org/10.1099/00222615-42-4-237

[74] Cooney, J., Kienle, Z., Foster, T.J. and O’Toole, P.W. (1993) The $\gamma$-Hemolysin Locus of Staphylococcus aureus Comprises Three Linked Genes, Two of Which Are Identical to the Genes for the F and S Components of Leukocidin. Infection and Immunity, 61, 768-771.

[75] Gouaux, E., Hobaugh, M. and Song, L. (1997) $\alpha$-Hemolysin, $\gamma$-Hemolysin, and Leukocidin from Staphylococcus aureus. Distant in Sequence but Similar in Structure. Protein Science, 6, 2631-2635. https://doi.org/10.1002/pro.5560061216

[76] Kamio, Y., Rahman, A., Nariya, H., Ozawa, T. and Izaki, K. (1993) The Two Staphylococcal Bi-Component Toxins, Leukocidin and Gamma-Hemolysin, Share One Component in Common. FEBS Letters, 321, 15-18. https://doi.org/10.1016/0014-5793(93)80611-W

[77] Colin, D.A., Mazurier, I., Sire, S. and Finck-Barbancon, V. (1994) Interaction of the Two Components of Leukocidin from Staphylococcus aureus with Human Polymorphonuclear Leukocyte Membranes: Sequential Binding and Subsequent Activation. Infection and Immunity, 62, 3184-3188.

[78] Alonzo, F., and, Torres, V.J. (2014) The Bicomponent Pore-Forming Leucocidins of 
Staphylococcus aureus. Microbiology and Molecular Biology Reviews, 78, 199-230. https://doi.org/10.1128/MMBR.00055-13

[79] Roblin, P., Guillet, V., Joubert, O., Keller, D., Erard, M., Maveyraud, L., et al. (2008) A Covalent S-F Heterodimer of Leucotoxin Reveals Molecular Plasticity of Beta-Barrel Pore-Forming Toxins. Proteins, 71, 485-496. https://doi.org/10.1002/prot.21900

[80] Malachowa, N., Whitney, A.R., Kobayashi, S.D., Sturdevant, D.E., Kennedy, A.D., Braughton, K.R., et al. (2011) Global Changes in Staphylococcus aureus Gene Expression in Human Blood. PLOS ONE, 6, e18617. https://doi.org/10.1371/journal.pone.0018617

[81] Supersac, G., Piemont, Y., Kubina, M., Prevost, G. and Foster, T.J. (1998) Assessment of the Role of $\gamma$-Toxin in Experimental Endophthalmitis Using A hlg- Deficient Mutant of Staphylococcus aureus. Microbial Pathogenesis, 24, 241-251. https://doi.org/10.1006/mpat.1997.0192

[82] Clyne, M., De Azavedo, J., Carlson, E. and Arbuthnott, J. (1988) Production of $\gamma$-Hemolysin and Lack of Production of $\alpha$-Hemolysin by Staphylococcus aureus Strains Associated with Toxic Shock Syndrome. Journal of Clinical Microbiology, 26, 535-539.

[83] Siqueira, J.A., Speeg-Schatz, C., Freitas, F.I., Sahel, J., Monteil, H. and Prevost, G. (1997) Channel-Forming Leucotoxins from Staphylococcus aureus Cause Severe Inflammatory Reactions in a Rabbit Eye Model. Journal of Medical Microbiology, 46, 486-494. https://doi.org/10.1099/00222615-46-6-486

[84] Venugopal, R.M. (2013) In Silico Molecular Interaction Studies of Gamma-Hemolysin of Staphylococcus aureus with Flavonoid Compounds. Trends in Bioinformatics, 6, 91-100. https://doi.org/10.3923/tb.2013.91.100

[85] Chowdhury, T. (2014) Virtual Screening of Compounds Derived from Garcinia Pedunculata as an Inhibitor of Gamma Hemolysin Component A of Staphylococcus aureus. Bangladesh Journal of Pharmacology, 9, 67-71. https://doi.org/10.3329/bjp.v9i1.17368

[86] Panton, P.N. and Valentine, F.C.O. (1932) Staphylococcal Toxin. The Lancet, 219, 506-508. https://doi.org/10.1016/S0140-6736(01)24468-7

[87] Loffler, B., Hussain, M., Grundmeier, M., Bruck, M., Holzinger, D., Varga, G., et al. (2010) Staphylococcus aureus Panton-Valentine Leukocidin Is a Very Potent Cytotoxic Factor for Human Neutrophils. PLoS Pathogens, 6, e1000715. https://doi.org/10.1371/journal.ppat.1000715

[88] O’Hara, F.P., Guex, N., Word, J.M., Miller, L.A., Becker, J.A., Walsh, S.L., et al. (2008) A Geographic Variant of the Staphylococcus aureus Panton-Valentine Leukocidin Toxin and the Origin of Community-Associated Methicillin-Resistant $S$. aureus USA300. The Journal of Infectious Disease, 197, 187-194. https://doi.org/10.1086/524684

[89] Woodin, A.M. (1960) Purification of the Two Components of Leucocidin from Staphylococcus aureus. Biochemical Journal, 75, 158-165.

https://doi.org/10.1042/bj0750158

[90] Prevost, G., Cribier, B., Couppie, P., Petiau, P., Supersac, G., Finck-Barbancon, V., et al. (1995) Panton-Valentine Leucocidin and $\gamma$-Hemolysin from Staphylococcus aureus ATCC 49775 Are Encoded by Distinct Genetic Loci and Have Different Biological Activities. Infection and Immunity, 63, 4121-4129.

[91] Prevost, G., Mourey, L., Colin, D.A. and Menestrina, G. (2001) Staphylococcal Pore-Forming Toxins. Current Topics in Microbiology and Immunology, 257, 
53-83. https://doi.org/10.1007/978-3-642-56508-3_4

[92] Lina, G., Piemont, Y., Godail-Gamot, F., Bes, M., Peter, M.O., Gauduchon, V., et al. (1999) Involvement of Panton-Valentine Leukocidin-Producing Staphylococcus aureus in Primary Skin Infections and Pneumonia. Clinical Infectious Diseases, 29, 1128-1132. https://doi.org/10.1086/313461

[93] Boussaud, V., Parrot, A., Mayaud, C., Wislez, M., Antoine, M., Picard, C., et al. (2003) Life-Threatening Hemoptysis in Adults with Community-Acquired Pneumonia Due to Panton-Valentine Leukocidin-Secreting Staphylococcus aureus. Intensive Care Medicine, 29, 1840-1843. https://doi.org/10.1007/s00134-003-1918-5

[94] Osterlund, A., Kahlmeter, G., Bieber, L., Runehagen, A. and Breider, J.M. (2002) Intrafamilial Spread of Highly Virulent Staphylococcus aureus Strains Carrying the Gene for Panton-Valentine Leukocidin. Scandinavian Journal of Infectious Diseases, 34, 763-764. https://doi.org/10.1080/00365540260348554

[95] Van der Flier, M., van Dijk, N.B., Fluit, A.C., Fleer, A., Wolfs, T.F. and van Gestel, J.P. (2003) Fatal Pneumonia in an Adolescent Due to Community-Acquired Methicillin-Resistant Staphylococcus aureus Positive for Panton-Valentine-Leukocidin. Nederlands Tijdschrift voor Geneeskunde, 147, 1076-1079.

[96] Klein, J.L., Petrovic, Z., Treacher, D. and Edgeworth, J. (2003) Severe Community-Acquired Pneumonia Caused by Panton-Valentine Leuko-Cidin-Positive Staphylococcus aureus. First Reported Case in the United Kingdom. Intensive Care Medicine, 29, 1399. https://doi.org/10.1007/s00134-003-1844-6

[97] Costello, M.E.H. and Huygens, F. (2011) Diversity of Community Acquired MRSA Carrying the PVL Gene in Queensland and New South Wales, Australia. European Journal of Clinical Microbiology \& Infectious Diseases, 30, 1163-1167. https://doi.org/10.1007/s10096-011-1203-4

[98] Vandenesch, F., Naimi, T., Enright, M.C., Lina, G., Nimmo, G.R., Heffernan, H., Liassine, N., Bes, M., Greenland, T., Reverdy, M.E. and Etienne, J. (2003) Community-acquired Methicillin-Resistant Staphylococcus aureus Carrying Panton-Valentine Leukocidin Genes: Worldwide Emergence. Emerging Infectious Diseases, 9, 978-984. https://doi.org/10.3201/eid0908.030089

[99] Gillet BI, Y., Vanhems, P., et al. (2002) Association between Staphylococcus aureus Strains Carrying Gene for Panton-Valentine Leukocidin and Highly Lethal Necrotising Pneumonia in Young Immunocompetent Patients. The Lancet, 359, 753-759. https://doi.org/10.1016/S0140-6736(02)07877-7

[100] Wiseman, G.M. (1975) The Hemolysins of Staphylococcus aureus. Bacteriological Reviews, 39, 317-344.

[101] Schmitz, F.J., Veldkamp, K.E., Van Kessel, K.P., Verhoef, J. and Van Strijp, J.A. (1997) $\delta$-Toxin from Staphylococcus aureus as a Costimulator of Human Neutrophil Oxidative Burst. The Journal of Infectious Diseases, 176, 1531-1537. https://doi.org/10.1086/514152

[102] Vandenesch, F., Lina, G. and Henry, T. (2012) Staphylococcus aureus Hemolysins, Bi-Component Leukocidins, and Cytolytic Peptides: A Redundant Arsenal of Membrane-Damaging Virulence Factors? Frontiers in Cellular and Infection Microbiology, 2, 12. https://doi.org/10.3389/fcimb.2012.00012

[103] Scheifele, D.W. and Bjornson, G.L. (1988) $\delta$ Toxin Activity in Coagulase-Negative Staphylococci from the Bowels of Neonates. Journal of Clinical Microbiology, 26, 279-282.

[104] Nakamura, Y., Oscherwitz, J., Cease, K.B., Chan, S.M., Munoz-Planillo, R., Hasegawa, M., et al. (2013) Staphylococcus $\delta$-Toxin Induces Allergic Skin Disease by Acti- 
vating Mast Cells. Nature, 503, 397-401. https://doi.org/10.1038/nature12655

[105] Traber, K. and Novick, R. (2006) A Slipped-Mispairing Mutation in AgrA of Laboratory Strains and Clinical Isolates Results in Delayed Activation of agr and Failure to Translate $\delta$ - and $\alpha$-Haemolysins. Molecular Microbiology, 59, 1519-1530. https://doi.org/10.1111/j.1365-2958.2006.04986.x

[106] Janzon, L., Lofdahl, S. and Arvidson, S. (1989) Identification and Nucleotide Sequence of the $\delta$-Lysin Gene, hld, Adjacent to the Accessory Gene Regulator (agr) of Staphylococcus aureus. Molecular Genetics and Genomics, 219, 480-485. https://doi.org/10.1007/BF00259623

[107] Gagnaire, J., Dauwalder, O., Boisset, S., Khau, D., Freydiere, A.M., Ader, F., et al. (2012) Detection of Staphylococcus aureus $\delta$-Toxin Production by Whole-Cell MALDI-TOF Mass Spectrometry. PLoS ONE, 7, e40660.

https://doi.org/10.1371/journal.pone.0040660

[108] Moraveji, Z., Tabatabaei, M., Shirzad Aski, H. and Khoshbakht, R. (2014) Characterization of Hemolysins of Staphylococcus Strains Isolated from Human and Bovine, Southern Iran. Iranian Journal of Veterinary Research, 15, 326-330.

[109] Coia, J.E., Browning, L., Haines, L., Birkbeck, T.H. and Platt, D.J. (1992) Comparison of Enterotoxins and Haemolysins Produced by Methicillin-Resistant (MRSA) and Sensitive (MSSA) Staphylococcus aureus. Journal of Medical Microbiology, 36, 164-171. https://doi.org/10.1099/00222615-36-3-164

[110] Cafiso, V., Bertuccio, T., Spina, D., Purrello, S., Blandino, G. and Stefani, S. (2012) A Novel $\delta$-Hemolysis Screening Method for Detecting Heteroresistant Vancomycin-Intermediate Staphylococcus aureus and Vancomycin-Intermediate $S$. aureus. Journal of Clinical Microbiology, 50, 1742-1744. https://doi.org/10.1128/JCM.06307-11

[111] Khawlah, K. and Ali, Z.F. (2014) Effect of CD-Cholesterol on Activity of $\alpha$-Hemolysin Production by Methicillin Resistant Staphylococcus aureus (MRSA). International Journal of Advanced Research, 2, 391-393.

[112] Tavares, A., Nielsen, J.B., Boye, K., Rohde, S., Paulo, A.C., Westh, H., et al. (2014) Insights into $\alpha$-Hemolysin (Hla) Evolution and Expression among Staphylococcus aureus Clones with Hospital and Community Origin. PLOS ONE, 9, 98634. https://doi.org/10.1371/journal.pone.0098634 